\title{
From union inspired to industry led: how Australian labour's training reform experiment turned sour
}

\author{
Tony Brown \\ Centre for Popular Education, \\ University of Technology, Sydney
}

Brown, T. (2006) 'From union inspired to industry led: how Australian labour's training reform experiment turned sour', Journal of Industrial Relations, 48: 4, September, 491505.

\begin{abstract}
Australian labour set out on a grand attempt to restructure vocational education and training in the 1980s and 1990s. The reforms were intended to go beyond the scope of previous worker education by aiming at complete systemic change by linking skill development to wages through the award system.

This paper locates labour's training reform in the wider program of economic modernisation. It argues that unions provided the inspiration for the new system but by the early 1990s had lost the initiative as enterprise bargaining was introduced and as employer associations and state education bureaucracies re-asserted control and established a new training market.

That training reform's original expectations were not delivered demands closer attention and analysis. Learning the lessons of this experiment is an essential step for labour in developing a positive agenda for workers' education in the future.
\end{abstract}

\section{Introduction}

When Australia's National Training Authority (ANTA) embarked on its consultation for the third national strategy for vocational education and training (VET) in 2003 one principle was taken for granted. VET is to continue to be 'industry-led', because 'Industry leadership is critical, (it is) a deliberate and distinctive characteristic of our national system.' (ANTA, 6)

This central underlying principle is now almost unchallenged and is supported by peak education and training bodies, state governments, business groups and key university VET research centres. In its own way the ACTU, (Australian Council of Trade Unions) despite misgivings about the administration of training and its sidelining from policy input since the election of the Howard government in the mid 1990s, also endorsed this position at its 2003 Congress. (Chappell and Hawke 2003, ACTU 2003b). 
But that is a far cry from the early days of training reform when trade unions provided the inspiration for the reforms implemented by Labor governments between 1983 and 1996. Then the labour movement, and the union movement in particular set out to restructure the entire vocational training system and to tie the changes to the industrial award system. This was achieved by linking skills and qualifications to award classifications. Whereas trade unions had in the past concentrated on setting up education programs and institutions that focussed on the trade union training, cadre training or workers education, training reform under Labor in the 1980s and 1990s aimed at complete systemic change. ${ }^{\mathrm{i}}$ (Boughton 1997, Brown 2003, Ewer et al 1991, Taksa 2003)

How then did this shift come about? This paper examines key turning points from when labour was shaping the restructuring of post school education and training to today's situation where industry's influence is seemingly hegemonic. It begins by briefly locating training reform in labour's wider agenda of modernising the Australian economy. It then considers training reform in three phases of union leadership through development, ebb and wane. Unions hoped that their interpretation of 'industry', which they understood to mean tripartite arrangements, would survive. Instead as business and the education bureaucracies asserted their influence 'industry' has come to be synonymous with 'business'. The paper draws on the experiences and reflections of a number of union officials who were instrumental in implementing training reform policies and who were members of national tripartite committees and inquiries. The paper concludes with an assessment of labour's experiment.

\section{Methodology}

The data collected for this paper is drawn from a wider study into the labour movement's expectations and assessment of training reform under the Labor governments of Bob Hawke and Paul Keating. Structured interviews were conducted with seventeen key labour movement figures around a series of critical incidents.

Of the seventeen, sixteen were trade union officials during the training reform period. The other was a Federal Minister in the Hawke and Keating Labor governments between 1990-1996, including periods as a Minister with Education responsibilities and for a time a member of Cabinet. Those interviewed were chosen because of their involvement in the union movement's development of training reform policies and strategies or because they were members of senior union bodies involved in education and/or industry restructuring. Some worked on the major restructured awards of the time (for instance the Metal Industry Award, the Child Care Award, the Textile, Clothing and Footwear Award), participated on the Australia Reconstructed study tour, on national or industry education bodies, or were responsible for educating other unionists about the training reform agenda. All had the benefit of hindsight and were being asked to reflect on the expected benefits more than ten years later.

The interviewees came from blue and white collar work areas. Two worked at the Trade Union Training Authority, one for the ACTU and another for a State Labor Council. Two were ACTU Executive members. Four worked at the metalworkers union (AMWU). Three did not want to be publicly identified. More men (12) than women (5) 
were interviewed, and more people associated with the 'left' (11 with clear allegiances) in union factional terms than from the 'right' (2).

Following each interview a full transcript was made and returned to the interviewees who were then invited to make any alterations, amendments or corrections they felt would better reflect their understanding and position. It is these 'corrected' transcripts that form the basis of the material referred to here.

What then is involved in this approach? The interviews sought to develop a story of the evolution of training reform and restructuring from the point of view of a group of union officials closely involved with policy development and implementation. It is not intended to be a definitive story. The research is an attempt to draw together different experiences and perspectives so that a richer picture of labour's training reform experiment can be examined. It aims to transform the various accounts into an 'interpretive one in search of meaning' (Geertz 1975,5) is the intention of constructing history that serves the collective purpose of better understanding that history in order to avoid the pitfalls and disappointments encountered in the 1980s and 1990s and to be better prepared for future interventions.

\section{Shaping national advantage}

The main education priorities of the Whitlam and first Hawke governments were focussed on schools and universities. It was not until the mid 1980s that a number of key unions and the ACTU began to see vocational education as an important part of Australia's education system.

Across the labour movement's political spectrum it was accepted that the movement's survival, and the living standards of those they represented, depended on making Australian capitalism more modern, technologically responsive and internationally competitive. A restructured education and training system, based on competency standards, would contribute to each of these goals and improve the prospects of individuals through investments in their human capital. These assumptions, shared by other social democratic governments around the world, were interwoven through the strategies and policy developments of Labor's terms in office. (Coates 2000)

Labour saw the potential for linking education and training with industrial relations and work reorganisation. It was seen as the linchpin in improving workers living standards and in entrenching unions' position in society, in overcoming declining trade union membership, and in redressing the 'export' of jobs from the industrialised to the newly industrialising nations.

By the early 1990s the collection of reports, new institutions, bureaucratic structures and national agreements had been brought together under an all-embracing umbrella known as the 'national training reform agenda'. Trade unions and government devoted enormous attention and human resources to reshape vocational education and training as skill formation was established as a national priority in modernising the Australian economy. 
As Labor's education policies evolved and expanded to embrace vocational education and training along with school and university education, trade unionists became prominent as promoters and leaders of reform. They sat on, or chaired, bodies such as the National Board of Employment, Education and Training (NBEET), the Employment and Skills Formation Council (ESFC), the Schools Council (SC), the Higher Education Council (HEC), the National Training Board (NTB), the Standards and Curriculum Council (SCC) and the Australian National Training Authority (ANTA). The training reform agenda became one of the foundations of the agreement between Labor and the ACTU.

The advocates of this reform strategy, built around what was to become known as a high wage / high skill strategy, contrasted their position with what they identified as Australian labour's traditional 'labourist' orientation, an orientation they identified as being the dominant trend in Australian labour history. (Ewer et al 1991) They saw labourism as a narrowly focussed, economistic view of what workers and workers' organisations could achieve under capitalism. Offering no challenge to the system of exploitation, labourism identified unions' role as being primarily concerned with the bread and butter issues of obtaining wage rises and defending working conditions. This view they contrasted with a more modern expression of labour's 'radical' tradition that now included social and economic policies. Industry policy, investment, welfare, superannuation, education and training, in addition to wages policy, were features of this new agenda.

Both wings of the labour movement were interested in this but the political and intellectual impetus for training reform came from within the unions, and especially those unions associated with the Communist Party and the left of the ALP.

Australia's new Labor government in 1983 saw economic policy as having one central question: how should national (or regional) competitiveness be created and maintained? Everything else - from macroeconomic policies to strategies for training and welfare flowed from this question.

According to this view, it was imperative to have a strategic trade policy to get new products developed and into markets as quickly as possible. Since technological change is a continual process of building up technical skills, capacity and entrepreneurship, a 'technological dynamism' needed to be nourished. Education and technological innovation became critical to the process. (Albo 1997)

In the absence of a modernising capitalist class the task fell to the forward looking, nation-building social democrats allied in both the political and industrial wings through the Accord. This new relationship provided the opportunity for Labor to shape Australia's advantage in a way that had not occurred since the Second World War.

A three-cornered policy involving progressive competitiveness, shared austerity, and international coordination was developed in keeping with the idea of shaped advantage. The progressive competitiveness strategy emphasised the effects of external constraints imposed by the new 'globalisation'. ii The argument went that in a globalised market a pre-condition of competitiveness is an economy and financial system that is open to 
international trade and exchange. But what distinguishes one economy from another are the skills of its labour force and the nature of workplace relations. Training policies should, therefore, be the central component of a jobs and welfare strategy, while relationships of 'trust' and co-operation should be fostered within enterprises. This approach permeated the training and workplace reform agenda.

The shared austerity strategy stressed the internal constraints necessary to foster growth. Full employment required restraint on workers' pay and consumption to keep exports competitive, investment high, and the state's budget under control. The role of an incomes policy was to spread work through wage restraint and keep unit labour costs down for exports. The Prices and Incomes Accord was the overarching policy framework for this approach.

Thirdly, international coordination relied on a Keynesian-style approach, which maintained that removing constraints on the market required the political will to shift expansionary policies from the national to the supranational level. What was needed, according to this view, was international co-ordination of economic policy. A 'cosmopolitan democracy' imposed on global governance structures would legitimate that kind of international co-ordination, while leaving questions of internal democracy to the ruling regimes of the region. Australia's regional approach was focused on bilateral trading relations with countries such as Indonesia and Japan and on developing new multi-lateral agreements such as APEC (Asia Pacific Economic Co-operation).

Labor's leaders, most effectively Paul Keating, successfully corralled their opponents to accept a simple alternative. Either they were for the future or the past.

\section{The ebb and flow of training reform}

The history of training reform under Labor falls into three phases. The first, from the mid-1980s, is one of ascendancy as the trade unions laid the groundwork and seized the initiative. Julius Roe, Assistant General Secretary of the AMWU ${ }^{\mathrm{iii}}$ and the ACTU's nominee on the National Training Board, gave four reasons in 1995 why unions supported training reform,

- the increasing openness of the Australian economy to the world, [meant] that a competitive economy should adopt a high skill / high wage path to build a high quality infrastructure,

- because the nature and quality of available education and training needed to change to meet the imperatives of a new labour force and economy,

- access to education and training was highly inequitable and workplace change had the potential to increase this inequity without union intervention. A more open economy meant greater labour mobility [raising] the need for a national system of skill and qualifications recognition. A tripartite, industry determined set of standards for the performance of work was developed to meet this need,

- education and training [is] a means of challenging the ideological drive for market relations to determine the future shape of education and training through deregulation and privatisation. (Roe, 1995) 
By the early 1990s employer associations and the education bureaucracy, especially in the state government departments, began to wrest back control of the training agenda, a momentum that has accelerated since 1996. But it was the rise of enterprise bargaining in 1991-92, the ALP government's promotion of it and unions' acceptance of it, which is most strongly identified by the interviewed union officials as the cause of labour's steady decline through the later 1990s. It is this latter period of labour's waning influence that is the main focus of this paper.

The first restructured award approved by the Industrial Commission was the Metal Industry Award and it did not take force until March 1990. The insertion of a new Clause $6 \mathrm{c}$ formalised the link between award restructuring and training at an industry level and was a landmark in the evolution of the training reform agenda. In it the parties 'recognised that in order to increase the efficiency, productivity and international competitiveness of industry, a greater commitment to training and skill development is required.'

Metalworker officials believed that the next milestone would be achieved by making paid training leave an award provision. The expectation was that like previous changes to the Metal Industry award inserting a paid training leave clause would eventually flow on to awards in other industries. The AMWU was engaged in an industrial dispute over the paid training leave issue and was preparing to take strike action to win its demand. At the same time a new Accord VI had been re-negotiated in the run-up to the 1990 Federal election and it introduced elements of enterprise bargaining alongside award restructuring. Chris Lloyd and Peter Ewer were AMWU national research officers and they believed the union was in a very strong position to win on the training leave issue when it was put on hold by the union's leaders until after the election.

The decision to suspend the campaign triggered a split among the union's officers. For Lloyd the issue was crystal clear, 'The whole thing that tied unions to the Training Reform agenda was awards. Awards were supposed to enshrine the agenda... The unions lost any ability to play in the Training Reform agenda the minute they embraced enterprise bargaining, because the whole principle was to go across awards... Once you separate awards from the agenda, unions are out of it they've got no purpose. Really, its that simple.' (Lloyd 1997, 21-22)

Julius Roe saw it differently. Adopting a position that emphasised the unions' weakness in the face of the employers' restructuring he found it 'difficult to see an alternative strategy... One alternative strategy some people suggested [was to] retain a centralised wage system and not allow this bargaining at enterprise level. Well my experience was that even before we moved away from a centralised system employers were faced with globalisation, were restructuring at a local level and because our focus was on the centralised system we weren't in any way able to intervene in that process of restructuring. It was management led, management dominated, we responded to it, sometimes we responded with resistance, but generally when it comes to those things management has completely the upper hand. At least through our agenda when they look at restructuring in manufacturing they have to look at things like education and training, they've had to deal with an offensive union agenda at the same time as they've 
been restructuring. That means it's had some positives as well as some negatives, but I certainly wouldn't suggest that the outcomes have all been positive at the enterprise level.' (Roe 1997, 15)

Don Sutherland, an educator with the Trade Union Training Authority (TUTA) agreed that 'unions were under attack and the degree of energy that they could apply to the process was weakened. We just couldn't bring the force to bear to maintain direction and that's signalled in the compromises we were prepared to make about enterprise level training and the semi-deregulation of credentialing and standards setting and so on.' (Sutherland 1996, 15) Roe's and Sutherland's assessments are in contrast to the position that unions were setting the agenda and 'driving change'.

What started as an internal dispute within the AMWU over the pre-election decision to suspend the industrial campaign came into the open with the publication of an interview in Australian Left Review. In the interview Lloyd and Ewer argued that their union leadership's acceptance of enterprise bargaining would destroy award restructuring. (Curran 1991) In going public they broke the accepted AMWU behaviour of keeping disputes in-house and knew that their action would invite retribution and intimidation. It came swiftly and before the interview even saw the light of day in George Campbell's denunciation in The Weekend Australian. He claimed that the criticisms had no support and that if Lloyd cared to debate it he would '...crunch him into the ground' (Hannan 1990)

The tide for labour's training reform began to turn around 1991 and 1992. In October 1991 the Australian Industrial Relations Commission (AIRC) approved Enterprise Bargaining as a new wage principle and in 1992 the Industrial Relations Act was amended to provide for decentralised bargaining. It sapped Ewer's commitment and ended the self-described 'Accord apparatchik's belief that the Accord and award restructuring could deliver the benefits he and his colleagues had hoped for. 'When enterprise bargaining was launched onto an unsuspecting public by the Federal cabinet and the ACTU in 1991, that was when I basically had had enough of Accord politics.' (Ewer 1997, 1)

It wasn't that enterprise bargaining coincided with training reform's decline, according to Lloyd, rather enterprise bargaining was the cause. 'If you think award restructuring is a complex thing that requires ten years to put in place, giving it one year and then bringing in a system that's completely the opposite is bound to destroy it, isn't it?' (Lloyd 1997, 22)

Other union officials highlighted the negative impact of the introduction of enterprise bargaining at the workplace. Jack was a national trainer with the metalworkers and had for many years before been a shop steward and official at Sydney's Cockatoo Dockyard. 'These new terminologies creep in like 'the enterprise'. Now if I, and workers, continually refer to the enterprise then they become part of it. And you are not arguing about better wages and conditions you start sitting around a table talking about the poor boss and the state of their profits. So the enterprise can be used to disarm people because it makes them part of the process when clearly they have no control 
whatsoever. But the 'employer' is still there and that's a far stronger word and if that kind of word is used then people know where they stand. ' (Jack 1997, 11)

Lindsay Benfell also worked in the metal industry but was employed by the Electrical Trades Union (ETU). He thought that enterprise bargaining 'actually even made it worse, because people are being trained for the needs of the enterprise, they're much more focused on the welfare of the enterprise. Before, tradespeople, see their skills to be portable and they assume they [can] go from one industry to the next and there's no great drama. But once you start focusing on the enterprise and all the training is focused on the enterprise, people would have a smaller perspective of the world rather than an expanded one (...) The way the Training Reform agenda has been addressed here, actually conspires against a better understanding and a better ability to fight against privatisation and deregulation.' (Benfell 1997, 6)

The contradiction was also evident to those outside the industrial wing of the movement, who could recognise a transfer in workers' allegiance arising from the shift to an enterprise focus. A Cabinet Minister in the Hawke and Keating governments noted that 'much of this enterprise based culture and industrial relations and training reform at the enterprise level does seem to envisage a greater sense of commitment by the workforce to the particular enterprise rather than to the working class.' (Min 1996, 10)

By 1992-93 trade union leadership of training reform was over and a new training industry was replacing the unions' influence. As union influence fell away control returned to the education bureaucracy, and employer associations became more influential. Labor Education Minister John Dawkins' intention of creating an 'open training market' was being consolidated. On some important issues unions had turned a blind eye to the implications of introducing a market into what had traditionally been a regulated, public sector industry and this left many ill-equipped to respond to the new arguments of business and the economic rationalist inspired public service policy makers. Ewer describes a situation where union officials were reluctant to closely examine the rhetoric around an 'industry responsive VET system' for fear of uncovering a reality that did not accord with their own rhetoric. This reluctance was compounded by an unfounded bravado about how unions would dictate how the new system would operate.

'In 1987, we did not properly unpack the code about an industry responsive VET system. See that was the rhetoric, it wasn't about a market-based approach as it is now, that rhetoric was not explicit then, it was all about making it responsive to industry and that industry was $u s$, the training system was going to be responsive to $u s$, not to the employers. We were going to tell it what it needed to do and then it was going to do it and the employers were going to have to get used to it.' (Ewer 1997, 9) Instead something quite different unfolded.

Many union officials believed that the employers had been asleep at the wheel during the 1980s and as a result had achieved 'a regulated, semi-decentralised approach... The employers were fairly slow to start with to clue into that.' Then the Business Council of Australia (BCA) and other employer associations 'decided they were going to intervene and wrestle back and prevent unions from being able to work so successfully with 
government in getting the reform agenda underway.' They were joined in this by 'the conservative governments and the conservatives in the bureaucracy, [who] got their act together to promote... deregulating the standards and the training systems, all those things start around 1993.' Underneath it all Sutherland understands the employers' fightback was motivated by an assessment that 'the potential was emerging, the potential from the workers point of view.' (Sutherland 1996, 15)

Roe disagrees with his former metalworker colleagues' assessment that enterprise bargaining ushered in the decline of training reform. He has continued his involvement in training reform when many others had departed and in 2003 was appointed to the ANTA Board. He believes training reform is an ongoing project. Another explanation was therefore necessary for why such a shift in direction occurred in the early 1990s. The government's support for 'privatisation, small government and other anti-worker policies' came about because Labor ministers and key policy advisors were 'captured' by economic rationalists in the public sector and this had a great disorganising effect on the labour movement in general and training reform in particular. 'Pusey's work on the capture of the senior bureaucracy and the dominance of Treasury and Finance Department bureaucrats in the process is pretty critical ${ }^{\text {iv }}$ That's clearly the experience of our union in trying to influence government policy in the period.' (Roe 1997, 17, 6)

Officers in the ACTU and NSW Labor Council also witnessed the swing towards greater business and bureaucratic influence. 'Marlon'v was an officer with the NSW Labor Council and had also been a TUTA trainer, he saw 'the training reform agenda got captured by what became known as the training reform bureaucracy.' (Marlon 1997, 5) It wasn't that the activity changed according to Jane Carnegie, who went to work at the ACTU as an assistant to Laurie Carmichael, rather 'the dimensions and the forces changed in that period of 1992/93 onwards where the government was responsive to perspectives other than the union movement's. The BCA and ACCI (Australian Chamber of Commerce and Industry) began coming out with views of their own and began to question some of the initiatives because they thought they were being disadvantaged.' (Carnegie 1997, 10)

As the pressure built on the ALP in the lead-up to what most believed was the unwinnable 1993 election the BCA, other employers and the conservative governments on the National Training Board made a concerted push 'to completely unhitch the industrial and training agenda' according to Cathy Bloch a TUTA trainer and former assistant General Secretary of the NSW Teachers Federation. Many in the labour movement expected Labor to lose and this generated an urgency to try to consolidate the structural changes that had been introduced since 1987. 'Unhitching the requirement to link standards to classification structures as well as to awards marked for me a turning point. The unions, fearing that the National Training Board might be abolished, took a calculated risk that it was more important to maintain the fledgling system and so began a series of retreats.' (Bloch 1997, 11)

Once the system reverted to the control of the education bureaucracy 'it just proved to be so slow. It got caught up in the entrails of the whole grinding educational process, there were so many consultants running around there was almost nothing being delivered to workers really. We then moved away from centralised wage fixing and in 
the enterprise bargaining environment that kind of vision of people having transferable and portable skills, and skills paths, which people's imagination was very fired up by in the 80 s and early 90 s seems to have gone into sand... The union movement got more remote from it.' (Bloch 1997, 11)

For Bloch removing the link between training reform and awards changed it from being a powerful social agenda aimed at improving workers' educational opportunities and modernising industry and the economy to a technical system full of structures and committees. Her frustration at educators not understanding this salient point led to frustration. 'I used to have people from the TAFE sector explain the training reform agenda to me and they'd put MOVEET up there and they'd do this and they'd do that, and I'd say 'but they're structures to what purpose, what's the reason for all of this, why are we doing it?' And most TAFE people I came across, in my view, had no idea because the industrial stuff had just been excised, they were never told about it anyway.' (Bloch 1997, 11)

Accompanying this swing was a surge of new consulting businesses eager to take advantage of the intricacies involved in devising new competency standards, curriculum packages, classification systems, assessment procedures and so on. Enterprise bargaining gave these emerging businesses an added boost because it was in their financial interests to promote the enterprise focus. 'What is your reaction as a private consultant in the training industry to Enterprise Bargaining?', asked Lloyd, 'This is even bigger because this means that ICI will do something different to DuPont or Dow Chemicals. That's great, custom designed systems.' (Lloyd 1997, 23)

\section{Contradictions and critique}

Whether there was a precise moment or event that shifted the balance away from what the unions had hoped to achieve from training reform it is clear that it foundered on three essential and related contradictions and these came to a head in the early 1990s.

Training reform's link to industrial relations rested on the ongoing existence of a centralised arbitration and award system. Introducing a decentralised enterprise bargaining system undermined the national, industry focus and institutional arrangements that made labour's training reform model possible. Ensuring that curriculum, standards and qualifications would be portable and recognised across industries and states was an important selling point of training reform and this was put at risk by a new commitment to enterprise outcomes. Finally, training reform advocates' interventionist expectations for industry policy and industry development faltered on what they identified as the government's commitment to a 'deregulatory program.' With this shift to a more neo-liberal agenda in the early 1990s 'it was going to be very difficult to get support for a regulatory or interventionist VET regime.' (Ewer 1997, 11) These contradictions reflected the critical divide between a national approach to reform and a free-market approach.

From their vantage points in the metalworker's research unit and the ACTU, Peter Ewer and Jane Carnegie were two union officials most intimately involved in the evolution of 
training reform. Their reflections reveal a sense of lost opportunity, disillusion but also a recognition that there were flaws in the model. Ewer believes that talk of a 'high skill, high wage economy is simply a nonsense', while Carnegie concluded that 'the rhetoric of the high wage, high skill hasn't come about at all. ... The turning point for that was Working Nation (1994), a low skill, low wage industry policy.' (Ewer 1997, 6; Carnegie 1997, 12)

The positive reasons for supporting training reform still retain their validity but the wider expectations that surrounded and supported it could not have been realised without confronting more fundamental inequalities. 'Unless you are going to confront the distribution of a wider range of social inequalities rather than just training then income distribution is going to remain as polarised as it is now.' Why then were those relations of power not taken into account? I'm never too sure whether the answer isn't that the original project was never seen through or whether the original project was so fatally flawed it was incapable of being realised (...) Certainly, I think it is incontrovertible that the original model of award-based restructuring was never carried through to a satisfactory conclusion.' (Ewer 1997, 6)

The retreats and compromises had longer-term consequences as well. They reversed the original skill formation moves and laid the path for the Howard government to say 'we need to price ourselves back into jobs and smash trade unions that stand in the way of us doing that. I think that confirms the trajectory that we consciously or otherwise put ourselves on through Training Reform.' (Ewer 1997, 6)

There is a further aspect to this turnaround that deserves closer attention. The consensus that was an essential feature of the Accord and subsequently training reform created a climate within the labour movement where critical questioning was at best frowned upon and too often actively suppressed.

The accepted wisdom among training reform unionists that industry should lead education restructuring reflected a commitment to consensus politics but also simultaneously betrayed an unwillingness to confront head on just who would control workers' education.

Unions were deliberately vague on what was meant by 'industry'. They used the term to mean tripartite arrangements, that is, business, government and unions co-operating in national and industry bodies. That was the modus operandi of the Labor government as well who came into office in 1983 with the Accord as the emblem of its commitment to 'consensus'.

The way vocational education was delivered was an important focus of the change process because what was delivered was determined by educational institutions, which in practice meant TAFE. Leading unions and business were agreed that the control of curriculum and standards should be removed from the hands of educators and education unions. 'The whole focus of the training system shifted, the relationship between who the training system serves changed dramatically' with 'the notion that industry really should take the lead role in determining the content outcomes, and those content outcomes reflecting industry's direct needs.' (Carnegie 1997, 2, 9) 
Ewer's comments above reveal unions did not 'unpack the code' hoping that their interpretation of what industry meant would continue unchallenged. The reluctance to openly advocate their interpretation coupled with an atmosphere within the labour movement that silenced dissent was a significant factor in disarming the movement's ability to understand change as it occurred and equip itself to resist the employers' intellectual and industrial offensive through the 1990s.

These pressures for consensus with employers and the state for the 'national interest' were not new. In the early twentieth century the Australian labour movement 'effectively resisted the education in citizenship (associated with social harmony and efficiency) that sought to transform its industrial culture'. (Taksa 2003, 14) As the long post war economic boom ended the pressure on labour to deliver consensus was strong. It was possible to resist but it required political leadership to do so, and equally required political leadership to consent. ${ }^{\mathrm{vi}}$

Ensuring consensus was maintained involved taking harsh steps against both individuals and unions who expressed dissent or stepped outside prescribed union or industrial court guidelines. (Brown 2004) Buchanan and Pocock point to an intellectual and organisational legacy of policy atrophy that is directly connected to the 'limited nature of debate' within the labour movement. They concluded that 'one of the greatest weaknesses of the Accord period was the limited nature of the debate about alternatives to the dominant ACTU-ALP leadership line.' (Buchanan \& Pocock 2002, 132)

\section{Conclusion}

Inevitably there was a high price to pay for inhibiting discussion and debate. When business peak bodies and the state bureaucracies re-asserted their interests, and especially when Howard was elected, they quickly and easily reclaimed 'industry' to mean business and in so doing sidelined union involvement in vocational education reform.

For more than a decade the ACTU and a handful of key unions created expectations that could not be delivered. The idea that workers' earnings, job security and work satisfaction could be substantially improved by establishing a new training system without also tackling economic inequality and power in the workplace was illusory. The underlying problem with the project was the belief that a consensus between labour, the employers and government would modernise the Australian economy for mutual benefits.

The system's intended gains were not delivered or at best were unevenly realised. The growing polarisation in income, high levels of unemployment, increased job insecurity and changes in the labour market such as growing numbers of casual and part-time workers are examples that highlight there was little gain from the pain of restructuring.

Many union officials most closely involved in developing the training reform agenda believe that Labor's acceptance of decentralised Enterprise Bargaining was the key 
factor that killed union training reform as it uncoupled awards and training and set in train a deregulatory momentum that has since been consolidated.

Suggestions that sustained advances could be achieved without confronting the issues of ownership and power and by avoiding conflict with the employing class were fundamentally flawed, and gradually contributed to the movement's weakened position.

New efforts are being made to revive union education to revitalise the movement (see for instance ACTU 1999, 2003a). In addition to the Organising Works program and the activities of the ACTU's Organising Centre a new set of unionism competencies have been endorsed by the Business Services Industry Training Board. As well the Australian Manufacturing Workers Union have embarked on an ambitious competency based accredited program for its officials and a Trade Union Education Foundation (TUEF) has received the support of the ACTU and the NSW and Victorian governments. These are important initiatives although they are different in nature and scope to the systemic restructuring proposed by the training reform agenda. A comprehensive appraisal of that experiment is still required by labour in order to prepare the next stage of union inspired education reform.

\section{References}

Albo G, (1997) A world market of opportunities? Capitalist obstacles and left economic policy. In: PANITCH L ed, Ruthless criticism of all that exists: Socialist Register 1997. London: Merlin Press.

Australian Council of Trade Unions (1999) Unions@work: the challenge for unions in creating a just and fair society. Melbourne: ACTU.

Australian Council of Trade Unions (2003a) Future Strategies: unions working for a fairer Australia. Melbourne: ACTU.

Australian Council of Trade Unions (2003b) Future of Work: Vocational Education and Training Background Paper ACTU Congress. Melbourne: ACTU.

Australian National Training Authority (2003) Shaping our future: a discussion starter for the next national strategy for vocational education and training 2004-2010. Brisbane: ANTA.

Boughton B.(1997) Educating the educators: The Communist Party of Australia and its influence on Australian adult education. Unpublished Ph D thesis. Bundoora: La Trobe University.

Brown A (2003) Labour movement views of post school education, training reform and economic restructuring in Australia between 1982 and 1995. Unpublished Ph D thesis. Sydney: University of Technology, Sydney.

Brown, T. (2004) Silencing dissent to win consent: national training reform in the Accord years. Labour and Industry. 15:1, 33-52.

Buchanan J \& Pocock P (2002) Responding to inequality today: eleven theses concerning the redesign of policies and agents for reform. Journal of Industrial Relations, 42, 108-135.

Chappell C \& Hawke G (2003) An industry-led system: issues for policy, practice and practitioners. Report 7 - integrating report, OVAL research working paper 03-07. Sydney: UTS. 
Coates D (2000) Models of capitalism: growth and stagnation in the modern era. Cambridge: Polity Press.

Curran C (1991) Interview with authors of 'Politics and the Accord'. Australian Left Review, 11 October

Economic Planning Advisory Council (1995) Globalisation: issues for Australia. Canberra: EPAC.

Ewer P, Hampson I, Lloyd C, Rainford J, Rix S, \& Smith M (1991) Politics and the Accord. Leichhardt: Pluto Press.

Geertz, C. (1975) Thick description: toward an interpretive theory of culture. The interpretation of cultures: selected essays. London: Hutchinson.

Hannan E (1990) Official under fire for blast at Accord. The Weekend Australian 30 June -1 July, 4

Latham M (1998) Civilising global capital: new thinking for Australian Labor, Sydney: Allen \& Unwin.

Lepani B, Freed G, Murphy P, \& McGillivray A (1995) Australia in the Global Economy. Canberra: AGPS.

Roe J (1995) Speech to the Australian National Training Authority national conference. Brisbane: ANTA.

Taksa L (2003) Education "from the working-class viewpoint" versus "instruction in civic efficiency": the Workers Educational Association, the Australian quest for national efficiency and struggles over citizenship. Draft paper Eighth National Conference, Australian Society for the Study of Labour History - Transforming Labour: Work, workers, struggle and change. 3-5 October, Brisbane.

Wood E M (1986) The retreat from class: a new 'true' socialism. London: Verso.

\section{Interviews with the author}

Benfell L (1997) Transcript of Interview. conducted 11 December 1997. Bloch C (1997) Transcript of Interview. conducted 17 January 1997. Carnegie J (1997) Transcript of Interview. conducted 25 September 1997. Ewer P (1997) Transcript of Interview. conducted 22 September 1997 Lloyd C (1997) Transcript of Interview. conducted 16 December 1997. 'Marlon' (1997) Transcript of Interview. conducted 24 March 1997. 'Min' (1996) Transcript of Interview. conducted 3 October 1996. Roe J (1997) Transcript of Interview. conducted 30 January 1997. Sutherland D (1996) Transcript of Interview. conducted 17 December 1996.

\section{Endnotes}

Two spellings of Labor and labour are used throughout this article. Labor is used for the political party, the Australian Labor Party (ALP) and for the NSW Labor Council the peak trade union body in NSW. Labour is used as a generic term for the labour movement, which embraces the political and industrial organisations of the workers' movement.

ii For an overview of the then contemporary mainstream Australian debate about responses to globalisation see EPAC 1995, Lepani et al 1995, and Latham 1998 for a more recent Labor version.

iii In the 1990s the AMWU was the Amalgamated Metal Workers Union. Today it is the Australian Manufacturing Workers Union (AMWU). 
iv Roe is referring to Michael Pusey's 1991 book Economic rationalism in Canberra: A nation building state changes its mind. Melbourne: Cambridge University Press.

$v \quad$ Neither Marlon, Jack nor the Minister wished to be identified for this study and therefore pseudonyms have been used.

vi Ellen M Wood's analysis of changes in the left's understanding of class and socialism The retreat from class (1986) is invaluable in assessing Australian political rethinking during this period. 